\title{
STUDENTS ARTICLES
}

\section{THE DISTRIBUTION OF LEGISLATIVE POWER IN RELATION TO LABOUR RELATIONS}

The need for industrial peace is more necessary and vital today than ever before. Because of the vast interprovincial enterprises, because of the great interdependence between these industries, and because of Canada's role in the world economy as an exporter, any industrial strife has detrimental effects on the whole economy of the nation. A steel strike in the East causes a slowup in construction in the West affecting the livelihood of hundreds of workers; a strike by the transportation agencies causes a major portion of the economy to grind to a halt; a strike in the pulp and paper industry causes foreign purchasers of these products to look for new sources of supply, with a resulting loss of markets for Canada. These and other examples show the dire need for means of preventing industrial strife and if it occurs for quick and efficient government action.

Because in Canada there is a division of legislative authority between the Dominion and the provinces, it becomes necessary to determine, if government action is required, to what extent labour relations are subject to the legislative jurisdiction of one or the other. By labour relations is meant the rights existing between an employer and his employees and how these are to be determined. Thus legislation as regards collective bargaining, fair labour standards, unfair labour practices, conciliation and arbitration touches some of the aspects of labour relations.'

The purpose of this short article is, firstly, to present the current constitutional position as regards the division of legislative authority over labour relations; secondly, to consider whether the division as it stands conforms to the present needs of Canada; and thirdly, if it does not, to suggest how the above needs may be better met.

As the British North America Act 1867 did not expressly grant the power to legislate as regards labour relations to either the Dominion or the provinces, it became necessary to determine which of the two had the power. To this question five answers or approaches were possible. Firstly, labour relations being essentially a problem concerning "property and civil rights" are therefore under the exclusive jurisdiction of the provinces. Secondly, labour relations being essentially of nation wide importance are therefore under the jurisdiction of the Dominion. Thirdly, labour relations being "property and civil rights" are under provincial jurisdiction, but labour relations in enterprises under the legislative jurisdiction of the Dominion are under Dominion jurisdiction; if there is Dominion legislation the provincial legislation becomes inoperative. Fourthly, labour relations in enterprises under provincial legislative jurisdiction are exclusively subject to provincial jurisdiction; and labour 
relations in enterprises under Dominion jurisdiction are exclusively subject to Dominion jurisdiction. Fifthly, labour relations in enterprises of a purely local nature are under exclusive provincial jurisdiction; and labour relations in enterprises of an interprovincial or Dominion nature are under exclusive Dominion jurisdiction.

The first approach was argued by counsel for the railway in Grand Trunk Ry. Co. v. A-G of Can., where the validity of s. 1 of 4 Edw. 7. c. 31 of the Statutes of Canada which provided that no railway within the jurisdiction of Canada could contract out of the liability of paying damages for personal injuries to their servants, was questioned. The learned counsel, relying on Citizens Insurance Co. v. Parsons where it was beld that in general the regulation of contracts was a matter within "property and civil rights" (s.92 ss. 13 of the B.N.A. Act) and thus under the exclusive jurisdiction of the provinces, maintained that as the relationship between master and servant was contractual, the provinces alone could regulate it, and therefore the Dominion legislation was invalid. Lord Dunedin in rejecting this argument and holding the section valid said:

It seems to their Lordships that inamuch as these rallway corporations are the mere ereatures of the Dominion Legislature-which is admitted-it caniot be constdered out of the way that the Parliament which calls them into exintence should preseribe the terms which were to regulate the rolations of the employees to the corporation. It is true that, in 80 doing, it does touch what may be described as the eivil riphts of those employees."

No more need be said, therefore, of the first approach.

The second appraach, based on the belief that because labour relations were of national importance Parliament should thereby have jurisdiction over them, was shared by many in Canada. It was admitted that the provinces might legislate as regards the rights between employees and an employer when the employer was a purely provincial enterprise but only when there was no conflicting Dominion legislation." On this theory Parliament enacted the Industrial Disputes Investigation Act." The operation of the Act was, by the definition of the word "employer" limited to mining, transportation, and communication enterprises, and to public service utilities. However, by s. 63(1) it was provided that by mutual consent any employer and his employees could invoke the provisions of the Act. Thus the Act could be very wide in its.application. It further provided that upon an industrial dispute occurring an application could be made to the Minister of Labour who could appoint a Board of Investigation and Conciliation to hear the disputants. After a reference was made to the Minister a strike or lockout became illegal and penalties for breach thereof were provided in the Criminal Code. Powers of the Board Included the summoning of witnesses, inspection of documents and working premises, and of attempting to bring about a settlement. If no settlement was reached the Board was to make recommendations to the Minister.

The validity of this Act was first challenged in The Montreal Street Ry. Co. v. Board of Conciliation and Investigation.' At trial the Act was

a[1907) A.c. 6 .

(19a1), 7 App. Can, 86.

Abld. it 68 .

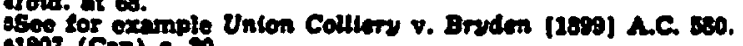

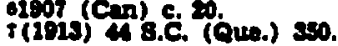


held intra vires. On appeal, in holding that the Act was valid and that it applied to the labour relations between employees and a local work, Greenshields J. stated:

While it may be true that rights or obligations ariaing between employer and employee in virtue of a contract are determined and must be determined by the civil law of the province of Quebee, yet a genernl statute controlling, as far as poscible, disputes and differences arising between an employer, and, not an Individual employee-but his employees generally, and which disputes and differences, if not regulated or settled, might result in a breach of the public peace and good order, is, in my opinion, a matter within the legdslative authority of the Dominion Parliament.

The validity of the Act and its applicability to the relations between employees and a municipal institution were questioned in Toronto Electric Commissioners v. Snider.' At trial Mowat J. upheld the validity of the Act and its applicability in the instant case on the ground that it was for the "peace, order, and good government" of Canada. On appeal Ferguson JA. delivering the majority judgment said:

... yet my opinion is that according to its "true nature and effect of the enactment", "lits pith and substance", the legislation is not law in relation to "municipal institutions" (8), "locel workes" (10), "property and eivil rights" (13), "matters purrely loenl" (16), as these words are used in s-as. 8, 10, 13, and 16 of 8. 92 of the BNA. Act, but is lesislation to authorize, and provide mnchinery for conducting an inquiry and investigation into industrial disputes between certain elasses of employers and their employees, which disputes in some cases may, and in other cases, will develop into disputes affecting not merely the immediate parties thereto, but the nattonal welfare, peace, order and aufety, and the national trade and buninews.10

This decision was appealed to the Judicial Committee of the Privy Council. In holding the whole Act ultra vires and thus rejecting the second approach, Viscount Haldane approached the matter in this way. He first considered whether the legislation could be validly enacted under s. 92. He held:

It is clear that this enactment was one which was competent to the legisiature of a Province under 8.92 . In the present case the substance of it was poedbly competent, not menely under the hoed of property and efvil rights in the Province, but also under that of muniejpal institutions in the Provinee. ${ }^{21}$

He next considered whether, although the legislation could be validly enacted under 8. 92, it could not also be enacted under the enumerated heads of s. 91 and thus still be valid. After discussing A-G for Ontario $v$. Reciprocal Inourers ${ }^{12}$ be held that the legislation could not be enacted under "Criminal Law".

It is obvious that these provisions dealt with civil rights, and it was not within the power of the Dominion Parliament to make this otherwise by imposing merely ancillary penalties. The penalty for breach of the restrictions did not sender the statute the leas an interference with civil rights in its pith and subatance.23

Secondly, he concluded that it did not come under the heading of "trade and commerce".

Nor does the invoention of the specific power in 3.91 to regulate trade and commerce assist the Dominion contention. . . The contracts of a particular trade or business could not, therefore, be dealt with by Dominion legislation so as to conflict with the powers asaigned to the Provinces over property and civil rights relating to the regulation of trede and commerce.".

stold. at soses.

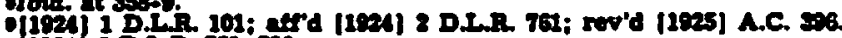

10 I0A 2 D.L.R T1, 700.

31 1025 A.C. 306,40

221024 A.C. 202

181025 A.C. 208.400.

isbid. at 100 . 
Thirdly, he held that the legislation could not be enacted under the "peace, order and good government" provision.

It appears to their Iordahips thet it is now not open to them, to troat Rursell $v$. The Quemis as having extablished the general principle that the mero fact that Dominion legialation is for the general advantage of Canado, or is sueh that it will meet a mere want which is felt throughout the Dominion, renders it compatent if it cannot be brought within the heads enumerated opeciftenly in 8. 91. Unleas this is 20 , if the subject matter folls within any of the enumerated heads in 8 . 92 such legialatton belongs excluatvely to Provineinal competeney. 30

And finally, he held that the legislation could not be maintained under the "emergency doctrine" because there was no emergency, nor was the legislation framed as such, viz. of temporary duration. Thus the second approach was rejected; nothing more need be said about it.

If the Snider case is widely construed greatly to limit Parliament's jurisdiction, ${ }^{20}$ and if it is considered in conjunction with the Grand Trunk case, it would follow that the fifth approach is also rejected and that the division of legislative authority is typified in the third approach; that is, that the provinces have jurisdiction to enact labour relations legislation for all enterprises but that this legislation becomes inoperative when the Dominion legislates on labour relations for an enterprise under its legislative authority. This view receives support from Re Hours of Labour..27 Duff J. in this case stated:

Under the acheme of diatribution of legialative authority in the BNA. Act 1867, logislative furisdiction touching the subject-matter of this convention is, subject to a qualification to be mentloned, primarlly vested in the Provinces. Under the bead of jurisdiction in s. 92 (13) or under ss. 16 or under both heade onch of the Provinces possesses authority to dive the force of law in the Province to provisions such as those contained in the draft convention. This genornl provision is subject to this qualifieation, namely, that as a rule a Provinee has no authority to regulate the hours of employment of the servants of the Daminion Government.

It is now settled that the Dominion in virtue of its authortty in respect of works and undertakings falling within its jurisdiction by foree of \&. 91 (20) and $\mathrm{s}$. 92(10) has certain powers of regulation touching the emplosment of percons ongaged on such worke or undertakings. The effect of such ledalation of the Dominion to exocution of this power is that provincial authority in relation to the subjeet-matter of such legislatton is superseded and remeins inoperative so long as the Dominion logialation continues in force.18

The Privy Council in the Labour Conventions case $e^{10}$ and in the Unemployment Insurance case ${ }^{20}$ did not deem it necessary to approve or disapprove of the decision of Duff $\mathrm{J}$.

However, there have been dicta and even decisions to the effect that in certain areas the Dominion's jurisdiction over labour relations is exclusive. If this were the case then the division of jurisdiction over labour relations would be as set out in the fourth approach. It will therefore be worthwhile to examine these cases in some detail.

Firstly, as regards Dominion Government employees the jurisdiction is exclusive. In Re Minimum Wage Act of Saskatchewan ${ }^{21}$ Taschereau J. held:

$15(1802)$. 7 App. Cat. 609.

is|19251 A.C. 306,412

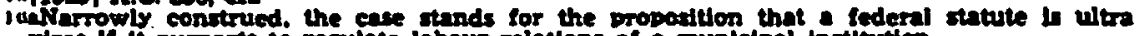
vires if if purports to resulate lobour relations of a muniejpal inititution.

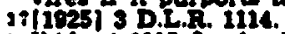

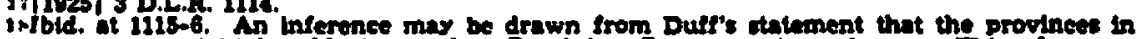
come cares mint be able to resulate Dominion Government employees. This of eourse is untrue as the sollowins diceurton will how.

$10 A-G$ for Con. $v$. A-G for Ont. $11037 \mid$ A.C. 23

unA-G for Can. v. A-G for Ont. Hest A.c. as.

al|194) 8.C.R. 24. 
It follows that the fixing of the wages of the Postal employees is a matter in pith and substance "Postal Service Legislation", upon which the provinces may not legislate without invading a field exclusively assigned to the Dominion.2:

Secondly, Dominion jurisdiction under s. 91(10), "Navigation and Shipping" is exclusive. In Pequet v. Pilots' Corporation Viscount Haldane said:

... it was, therefore, in their opinion, for the Dominion and not for the Provincial Legislature to deal exclusively with the subject of pilotage after Confederation. notwrithotanding that the civil rights and the property of the Corporation of Pilots of Quebec Harbour might incidentally, if unavoidably, be seriously affected. 24

In Reference Re Validity of Industrial Relations and Disputes Investigation Act ${ }^{2 s}$ Taschereau, Rand, Kellock, Estey, and Abbott JJ. also were of the opinion that the Dominion jurisdiction over labour relations under this head was exclusive. The other four judges did not deem it necessery to consider the question.

Thirdly, as regards Dominion jurisdiction under s. $92(10)$ the position is doubtful. In CPR. v. Notre Dame de Bonsecours ${ }^{20}$ Lord Watson said:

Accordingly, the Parliament of Canada has, in the opinion of their Lordahips. exclusive right to preseribe regulations for the construction, repair, and alteration of the rollway, and for it management. . .7

The opinion in Re Hours of Labour, to the effect that the jurisdiction is not exclusive has already been indicated. In C.P.R. v. A-G for B.C.,"3 -Lord Reid left the question open.

It is also, unneceseary for their Lordships to express any opinion on the question whether if the Empreas Fotel could be brought within the scope of either head 10(a) or head 10(c) of s. 92 of the B.N.A. Act, 1867, regulation of the hours of work of persons employed in it would be either within the exclusive legislative authority of the Parlianent of Caneda or within the domain in which provincial and Dominion leofislation may overlap.20

In the Industrial Relations case, Taschereau, Estey, and Abbott JJ. were of the opinion that the jurisdiction was exclusive. Kellock J. said it was unnecessary to decide but that it was probably exclusive. Rand $J$. thought it was not exclusive but held that this question did not have to be decided. Kerwin, Locke, Cartwright, and Fauteux JJ. did not consider the question or deemed that it was not necessary to decide. In Cant v. Canadien Bechtel Ltd. ${ }^{30}$ Boyd Co. Ct. J. thought that the jurisdiction was exclusive.

On principle and on weight of authority it may be that the Dominion has exclusive jurisdiction. It is submitted that there is no logical reason why the result should be any different when the Dominion claims its jurisdiction under s. 91 (10) or s. $92(10)$. However, in this whole question of exclusiveness the true position may be that where labour relations themselves are in pith and substance under an enumerated head of s. 91 then the Dominion jurisdiction is exclusive; if however, they are merely

221bid. at 257.

22[1920] A.C. 1028 .

serbed. at 1001 .

2s[1955) a D.I.R. 721.

28|100| A.C. 367.

saible at arz.

sel1950) A.C. 22

sofbld. at 14.

so(19s) 12 D.L.R. (2d) 215. 
ancillary to matters which are in pith and substance under s. 91 then the jurisdiction is not exclusive. This line of reasoning receives support from the fact that Rand J., although emphatic in stating that Parliament's jurisdiction over labour relations under s. 91 (10) was exclusive, believed that it was not exclusive under s. $92(10)$. If this is valid then the jurisdiction over labour relations is a combination of the third and fourth approaches; that is, the Dominion and the provinces each have exclusive jurisdiction over certain enterprises and overlapping jurisdictions over the other enterprises. In the area of overlapping jurisdiction Dominion legislation supersedes provincial legislation and makes it inoperative.

The general scheme of distribution of legislative power in relation to labour relations having been outlined; it is now appropriate to consider whether this distribution accords with the needs of Canads. It is submitted that enterprises of a purely local nature can be most effectively and efficiently regulated by provincial authority and that enterprises of an interprovincial or Dominion nature can be best regulated by the federal government. To the extent that the present position of distribution is not in conformity with the above submission, to that extent the needs of Canada are not being properly met. A statement by Dean Scott will best illustrate the point.

Two practical illustrations may be eiven of the difficulties and dangers that can arise through the Inadequacy of our present law deallng with industrial disputes. The first is the story of the strike in the packing industry in 1947. In that instance, there was a single union, the United Packinghouse Workers of America, acting as the bargoining agent for all important plants in eight out of the then nine Cansdian provinces. There were three dominant firms negotiating the now contract . . . Theoretically, before a natton-wide strike could be called separate provinclal negotintions should have been started in each province where there was a plant affected, with separate conciliation boards consisting of different people all investigating the same problem and making separate reports to zeparate Departments of Labour. What a legal absurdity! ... It is a personal opinion after some investigation of this siturtion, that hed federal authority existed there would have been no strike .. . .s1

What can be done to remedy this situation? Clearly the adoption of the fifth approach would be an ideal solution. Can this be done judicially today? In the face of the Snider case, Re Hours of Labour, the Labour Conventions case, and C.P.R. v. A-G for B.C. It seems very doubtful. In the last mentioned case Lord Reid said:

There are many companies beside the appellant whose businesses extend over all, or most of, the provinces. It was not, and could not be suggested that the Parliament of Canda could regulate the hours of work of employees of all such companies.

But their Lordships can find neither principle nor authority to support the competence of the Parliament of Canada to legislate on a matter which clearly falls within any of the enumerated heads in 8.82 and cannot be brought within any of the enumerated heads in a. 92 merely because the activities of one of the parties concerned in the matter have created a unified system which is wideapread and important in the Dominion.3y

What of amending the constitution to provide for the fifth approach? Dean Scott believes this is one way out of our present situation; however, currently there does not seem to be any public concern over the problem and in this light it is doubtful whether any amending will be done.

31Scott, Pederal Juriedtetion over Labour Relations-A New Look, (2060). MeCIII IJ. 153. at 161-2. Many other problems can arles which under the present eonntitutional potition can cause creat hardahips for the unions, manarement. and the people of Canada. $y=|1050|$ A.C. 122, 120. 
Although the courts at present could not categorically hold for the fifth approach as such, it is submitted that they could by sound judicial engineering within the framework of the existing legislative division approximate it to a very great extent. With the passing of the Industrial Relations and Disputes Investigation Act, and other related Acts," which cover all enterprises under federal authority, questions of jurisdiction will arise more and more for consideration. To bring out the problems that will be encountered more clearly and to devise some possible tests or criteria in solving them, a few select cases will be briefly considered.

In C.P.R. v. A-G for B.C. the issue was whether the British Columbia Hours of Work Act applied to the employees of the C.P.R. Empress Hotel in Victoria. Counsel for the railway argued that the hotel was an indivisible part of the railway undertaking and thus the B.C. Act was inapplicable. The Privy Council rejected this argument and held that the hotel was a separate undertaking. Lord Reid, however, made the following dictum:

It may be that if the appollant chose to conduct a hotel solely or even principally for the benefit of travellers on its system, that hotel would be a past of its railway undertaking."

In this case the emphasis seems to have been, therefore, on the quantitative use of a particular enterprise in determining its qualitative character; that is, whether it was under federal or provincial jurisdiction.

In A.G for Ont. v. Winner, a bus service carried on mainly for inter-state purposes was held to be under Dominion jurisdiction. In so holding the Privy Council emphasized the treating of an enterprise as a unified whole rather than as a composite of divisible parts. Lord Porter said:

The undertaking in queation is in fact one and indivisible. It is true that it might have been carried on differently and might have been limited to activities within or without the province, but it is not and their Lordships do not agree that the fact that It might be carried on otherwise then it is makes it or any part of it any the less an interconnecting undertaling.so

In Re Tank Truck Transport' only six per cent of a motor carrier's business was inter-provincial. In holding that the federal labour act applied to all the employees of the carrier McLennan J. said:

... If the focts show that a particular undertaking is continuous and regular as the undertaking is in this case, then it does in fact connect or extend and falls within the exception in 8 10 (a) regardless of whether it is of greater or less extent than that which is carried on within the province.an

In this case again the indivisibility concept was emphasized, whereas the quantitative element was minimized.

In the Industrial Relations case the issue was whether the federal Act applied to the clerical staff and stevedors of a company which was under contract to supply stevedors exclusively to shipping companies engaged in inter-state commerce. It was held that the Act applied to them as their activities came under "navigation and shipping."10 What if, how-

anCanada Patr Bmployment Practlees Act 1952-85 (Can) c. 10: Female Emplovees Baual Pay Act 1956 (Can) e. 30: Asntial Vocetions Aet 1357-55 (Cani c. 24.

atiosol A.C. $12,14$.

s3igst A.C. Sti.

anbid. at 501-3.

Mr(1901) 23 D.I.R. (2A) 161.

sarold. at 172 .

NoIn the litht of thl decleton. Fe Lunemburg Sea Products I29471 \& D.I.R. 105. In whleh It was held that erewa of shlps did not come under toderal Jurlediction for purposes of labour relations, ts probsbly no lonser sood lew. 
ever, the stevedors had worked only seveny-five or twenty-five per cent of their time for the inter-state shippers? Would the Act still apply to them? What if the company rather than having its own staff contracted with another company for clerical staff. Would this staff now come under the Act?

A limit on the extent of the federal jurisdiction under "navigation and shipping", was placed in Underwater Gas Developers Ltd. v. Ontario Labour Relations Board. 10 The business of the company in question (which operated solely intra-provincially) was to prepare sites for underwater drilling. For purposes of transporting supplies and workers from shore to the drilling site the company employed its own boats. In holding that the provincial labour act applied to all the workers Aylesworth J. A. said:

It would seem, therefore, that the majority of the learned Judges of the Supreme Court of Cande who at upon the roference were of the opinian that the busineas of nevigation and shipping or a business, the main object of which was navigation and shipping, when only intra-provinclal in scope and extent fell within the exclurive furiediction of the Province in which ruch business was carried on and was not embreced in Dominion juriediction under a. 21, head 10.42

In Pronto Uranium Mines Ltd. v. Ontario Labour Relations Board"s the issue was whether a company operating a uranium mine solely within the province of Ontario came under federal or provincial jurisdiction for labour relations purposes. MCLennan J. held:

... It would be incompatible with the power of Parliament to loglslate with

respect to the control of atomic energy for the peace, order, and government of Cannda if labour rolntions in the production of atomic enerdy did not lie within the regulation of Parliament.

In this case the emphasis seemed to have been on the intrinsic importance of the uranium mining industry to Canada, in holding that it came under federal jurisdiction. On this basis should not all the industries engaged in defence work also came under federal jurisdiction?

In Cant v. Canadian Bechtel Ltd." the issue was whether the employees of an engineering firm, engaged exclusively in the construction and management of an interprovincial oil pipeline came under federal or provincial labour relations jurisdictions. Boyd Co. Ct. J. held that as the interprovincial pipeline was an undertaking coming within s. 92(10) of the B.N.A. Act then the federal jurisdiction applied." What if in this case the company's object was merely to construct the pipeline? Would it still come under federal jurisdiction? If so, what would bappen after it finished the construction job and began constructing a pipeline which was totally intra-provincial? Would it still be under federal jurisdiction or would it then come under provincial control? These questions raise the very difficult problem of certainty and permanence of jurisdiction over a particular enterprise.

From the above brief consideration of cases certain criteria can be ascertained which may be used to determine whether any enterprise

$10(1960) 24$ D.L.R. (2d) 672.

IIfbid. at 602 .

$42|1956|$ O.R. 262.

- sibte. at $860-70$

(195) 12 D.LR. (2A) 21.

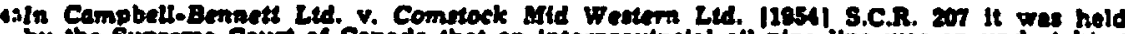
bo the supreme Court of Canede that an interprovinelal oll plpe line was an undertikins comlns within s. 2 (10) (a) of the B.N.A. Act. 
or part of it is or is not, as to labour relations, under federal jurisdiction and are as follows. Firstly, the enterprise has to be in some way related to an admitted head of federal jurisdiction. It would follow that the closer the relationship the more likelihood of the enterprise coming under federal control. Of course, if no relationship can be found that would end the matter.

Secondly, the intrinsic importance of the enterprise vis a vis Canada should be considered. Thus a company developing anti-missle defences would more likely come under federal control than a company which kept federal buildings in repair.

Thirdly, it is necessary to consider how much of the enterprise's operations are carried out for purposes federal in nature. Thus in the Empress Hotel case it was held that as the hotel was mainly used for general business it came under provincial jurisdiction. It was indicated, however, that had the hotel been used solely or mainly for the railway's passangers it might well have come under federal jurisdiction. It may be noted that this and the second criterion are very closely inter-related. Thus the greater the intrinsic importance of the enterprise to Canada the lesser an amount of its operations would have to be for federal purposes in order to bring it under federal jurisdiction. It would also follow that the greater its quantitative operations in the federal field, the greater would be its intrinsic importance to Canada, and vice versa.

Fourthly, it is necessary to determine whether the enterprise in question can be considered as a unit or as a composite of distinct or separate parts. In the Industriol Relations case it was held by the majority of the Supreme Court of Canada that federal jurisdiction applied to the whole company; that is, to both the stevedors and the clerical staff. Locke J., who dissented in part, was prepared to hold that it applied to stevedors but not to the clerical staff; that is, he was prepared to treat the company as composed of two parts: one coming under the federal and the other under provincial jurisdiction.

Finally the consideration of certainty and stability of jurisdiction has to be taken into account. Great uncertainty could arise because the applicable jurisdiction could change as the functions of a particular enterprise change. This uncertainty may be an unavoidable aspect of federalism; nevertheless, it would have to be considered in any given case and may well play an important role in its determination.

It is submitted that if our judiciary in applying these criteria wished to extend federal jurisdiction to a very great extent there is nothing preventing it from doing so. That this can be achieved is demonstrated by the decisions of the Supreme Court of the United States under the Wagner and Fair Labour Standards Acts. For example, in Borden Co. v. Borellate the issue was whether porters, elevator operators, and night watchmen working in a building housing the executive officers of a company that participated in inter-state commerce could be considered as engaged in an occupation "necessary to the production of goods for commerce." The Court held that they came within the definition and were thus subject to the Federal Fair Labour Standards Act. Murphy J. soid:

$40(243)$ a.s 8.8 .670$. 
The Kirahbaum ense inde it clear that the work of maintanance employees in - building where goods were physienlly mnnufnctured or procemed had usuch a close and immedinte tie with the process of production for commeree," and wes therefore 20 much an easantial part of it that the employees are to be regarded a engaged in an oceupation "necenung to the production of goods for comineree."

It may not be desirable for our courts to 80 to the extreme of practically eliminating provincial jurisdiction in this area as was done to the States' Jurisdiction by the Supreme Court of the United States; nevertheless, they should increase the federal jurisdiction to a much greater extent than it exists at present.

In conclusion, therefore, it can be said that there is a chasm between the needs of Canads today and the ability of governments to meet them by proper legislation. However, as has been pointed out, the situation is not beyond remedy. A social and economic minded judiciary could, and, it is strongly urged should, bring the constitutional position into conformity with the needs of Canada.

ANTON M. S. MOTNYK 